\author{
О. Ховпун, \\ кандидат юридичних наук, доцент, \\ завідувач кафедри кримінального права, процесу та криміналістики \\ Академії праці, соціальних відносин і туризму
}

\title{
ПРАВОВЕ РЕГУЛЮВАННЯ ДЕРЖАВНОГО НАГЛЯДУ У СФЕРІ РОЗДРІБНОЇ ТОРГІВЛІ ЛІКАРСЬКИМИ ЗАСОБАМИ
}

\begin{abstract}
Забезпечення охорони здоров'я людини й громадянина $€$ одним з основних завдань держави. Важливим напрямом забезпечення здоров'я людини є належна якість лікарських засобів, які громадяни можуть придбати в аптеці. Водночас здійснення державного нагляду за дотриманням аптеками правил роздрібної торгівлі лікарськими засобами та їхньою якістю $€$ одною з основних функцій уповноважених державних контролюючих органів у сфері обігу лікарських засобів.

Належне правове регулювання специфіки державного нагляду у сфері роздрібної торгівлі лікарськими засобами є запорукою виконання органом влади покладених на нього завдань i дотримання законних інтересів суб'єкта господарювання. Наведені аргументи обгрунтовують актуальність дослідження правового регулювання особливостей державного нагляду у сфері роздрібної торгівлі лікарськими засобами.
\end{abstract}

Проблеми державного нагляду в різних сферах господарської діяльності неодноразово досліджувалися науковцями-правознавцями: П.В. Синицький вивчав проблеми здійснення державного нагляду Державною службою охорони при МВС України [1, с. 15-18]; А.Л. Правдюк досліджував особливості державного нагляду за ветеринарним станом сільськогосподарських тварин [2, с. 74-84]; B.I. Теремецький, розглядаючи питання державного контролю й нагляду у сфері оподаткування, при- ділив увагу змісту й співвідношенню понять «контроль» $\mathrm{i}$ «нагляд» у цій сфері [3]. Доробки вказаних та інших науковців стали підгрунтям для теоретичних висновків щодо поняття державного нагляду в цій статті. Водночас особливості державного нагляду у сфері роздрібної торгівлі лікарськими засобами не були предметом дослідження названих науковців.

Правове регулювання роздрібної торгівлі лікарськими засобами також досліджувалося фахівцями у сфері права й фармації. Наприклад, О.С. Соловйов вивчав специфіку організації діяльності аптек. В його праці детально вивчена нормативно-правова база для відкриття аптеки та здійснення роздрібної торгівлі лікарськими засобами [4, с. 215-221]. Л.I. Кущ досліджувала особливості торгівлі лікарськими засобами як різновиду господарської діяльності [5, с. 29-34]. С.В. Васильєв вивчав нормативно-правове регулювання роздрібної торгівлі лікарськими засобами [6, с. 41-44]. Утім проблеми правового регулювання державного нагляду у сфері роздрібної торгівлі лікарськими засобами залишаються багато в чому недослідженими в юридичній літературі.

Мета статті полягає у визначенні особливостей правового регулювання державного нагляду у сфері роздрібної торгівлі лікарськими засобами.

Проблематика здійснення державного нагляду у різних сферах господарської діяльності й досі привертає 
увагу науковців. У доктрині адміністративного права сформувалися різні погляди щодо змісту й співвідношення діяльності, пов'язаної з державним наглядом і контролем. Однак вважаємо це питання достатньо вивченим на теоретичному рівні.

Сфера роздрібної торгівлі лікарськими засобами також неодноразово ставала об'єктом вивчення дослідників як у фармації, так і в юриспруденції. О.С. Соловйов стверджує, що у спеціальних нормативно-правових актах не врегульовано питання щодо побудови й структури системи управління якості саме в аптечних закладах, хоча ця система $€$ предметом державного контролю. Враховуючи наведене, термінового вирішення потребує питання систематизації нормативно-правової документації щодо організації діяльності аптечних закладів у напрямі узгодження норм, усунення дублювання, колізій, прогалин [4, с. 219]. Поділяючи думку дослідника, спробуємо визначити ті нормативно-правові акти, які становлять правову основу державного нагляду у сфері роздрібної торгівлі лікарськими засобами.

У результаті здійснених досліджень С.В. Васильєв визначає, що нормативно-правові засади роздрібної торгівлі лікарськими засобами встановлені в таких законодавчих актах, як Основи законодавства про охорону здоров'я від 19 листопада 1992 р., Закон України «Про лікарські засоби» від 4 квітня 1996 р. та Закон України «Про захист прав споживачів» від 12 травня 1991 р. Важливим підзаконним актом, який регулює правовідносини в цій сфері, $є$ Ліцензійні умови провадження господарської діяльності з роздрібної торгівлі лікарськими засобами [6, с. 43]. Але ці законодавчі й підзаконні акти регулюють роздрібну торгівлю лікарськими засобами, а не державний нагляд у цій сфері.

Л.І. Кущ пропонує визначати роздрібну торгівлю лікарськими засобами як господарсько-торговельну діяльність суб'єктів господарювання - аптек й аптечних кіосків (пунктів), що має допоміжний характер і спрямована на закупівлю, збереження й реалізацію цих засобів установам охорони здоров'я й населенню без права перепродажу [5, с. 31]. Не погоджуючись із твердженням науковця, що ця діяльність має допоміжний характер для аптек, наведемо законодавче визначення роздрібної торгівлі лікарськими засобами.

Правову основу роздрібної торгівлі лікарськими засобами становлять Закон України «Про лікарські засоби» та Ліцензійні умови провадження господарської діяльності 3 виробництва лікарських засобів, оптової та роздрібної торгівлі лікарськими засобами, імпорту лікарських засобів (крім активних фармацевтичних інгредієнтів), затверджені постановою Кабінету Міністрів України від 30 листопада 2016 р. № 929 (далі - Ліцензійні умови). Як установлено у ч. 1 ст. 19 Закону України «Про лікарські засоби», роздрібна торгівля лікарськими засобами на території України здійснюється підприємствами, установами, організаціями та фізичними особами-підприємцями на підставі ліцензіі, яка видається в порядку, встановленому законодавством. Відповідно до ч. 1 і ч. 2 ст. 21 Закону України «Про лікарські засоби» реалізація (відпуск) лікарських засобів громадянам здійснюється за рецептами й без рецептів лікарів. Забороняється реалізація (відпуск) громадянам неякісних лікарських засобів або таких, термін придатності яких минув або на які відсутній сертифікат якості, що видається виробником [7].

Офіційні визначення «роздрібної торгівлі лікарськими засобами» й «аптеки» містяться в Ліцензійних умовах. Відповідно до абз. 26 п. 3 Ліцензійних умов роздрібна торгівля лікарськими засобами визначається як діяльність 3 придбання, зберігання та продажу готових ліків, виготовлених (вироблених) в умовах аптеки, через аптеку та ї структурні підрозділи безпосередньо громадянам для особистого споживання, закладам охорони здоров'я 
(крім аптечних закладів), а також підприємствам, установам й організаціям без права їх подальшого перепродажу. Водночас, згідно з абз. 2 п. 3 Ліцензійних умов, аптекою визнається заклад охорони здоров'я, основним завданням якого є забезпечення населення, закладів охорони здоров'я, підприємств, установ й організацій лікарськими засобами [8]. Отже, доктринальне й законодавче визначення роздрібної торгівлі лікарськими засобами відзначають дві основні риси такої діяльності. По-перше, роздрібна торгівля лікарськими засобами здійснюється через аптеки. По-друге, іiі метою є забезпечення громадян лікарськими засобами.

Правову основу державного нагляду у сфері роздрібної торгівлі лікарськими засобами становлять:

- Закон України «Про основні засади державного нагляду (контролю) у сфері господарської діяльності» від 5 квітня 2007 р. [9];

- Положення про Державну службу України з лікарських засобів та контролю за наркотиками, затверджене Постановою Кабінету Міністрів України від 12 серпня 2015 р. (далі - Положення) [10];

- Ліцензійні умови провадження господарської діяльності 3 виробництва лікарських засобів, оптової та роздрібної торгівлі лікарськими засобами, імпорту лікарських засобів (крім активних фармацевтичних інгредієнтів), затверджені Постановою Кабінету Міністрів України від 30 листопада 2016 р. (далі - Ліцензійні умови) [8];

- Порядок контролю якості лікарських засобів під час оптової та роздрібної торгівлі, затверджений Наказом Міністерства охорони здоров'я України від 29 вересня 2014 р. (далі - Порядок контролю торгівлі) [11];

- Порядок відбору зразків лікарських засобів для лабораторного аналізу під час здійснення державного контролю якості таких засобів, затверджений Постановою Кабінету Міністрів України від 3 лютого 2010 р. (далі Порядок відбору зразків) [12];
- Критерії, за якими оцінюється ступінь ризику від провадження господарської діяльності у сфері виробництва лікарських засобів, оптової і роздрібної торгівлі лікарськими засобами, імпорту лікарських засобів (крім активних фармацевтичних інгредієнтів) та у сфері контролю якості лікарських засобів i визначається періодичність здійснення планових заходів державного нагляду (контролю) Державною службою лікарських засобів та контролю за наркотиками, затверджені Постановою Кабінету Міністрів України від 5 червня 2009 р. [13].

Закон України «Про основні засади державного нагляду (контролю) у сфері господарської діяльності» встановлює принципи державного нагляду, види наглядових заходів, повноваження органів влади й права суб'єктів господарювання під час здійснення державного нагляду у сфері господарської діяльності. У названому Законі детально регламентовані порядок і підстави проведення планових і позапланових перевірок органами державного нагляду, визначені права та обов'язки працівників суб'єкта господарювання під час проведення заходу державного нагляду [9]. Подібні контрольно-наглядові заходи можуть бути проведені й щодо аптек, які здійснюють роздрібну торгівлю лікарськими засобами.

Органом влади, який уповноважений здійснювати перевірки господарської діяльності аптек, є Державна служба 3 контролю якості лікарських засобів та контролю за наркотиками (далі - Держлікслужба). Згідно з п. 1 Положення Держлікслужба реалізує державну політику у сферах контролю якості та безпеки лікарських засобів, медичної техніки й виробів медичного призначення, а також обігу наркотичних засобів, психотропних речовин і прекурсорів, протидії незаконному їх обігу. Відповідно до пп. 9, 10, 13 П. 4 Положення Держлікслужба виконує такі функціі:

- здійснює державний контроль за дотриманням вимог законодавства 
щодо забезпечення якості й безпеки лікарських засобів і медичних виробів на всіх етапах обігу, у тому числі правил здійснення належних практик (виробничої, дистриб'юторської, зберігання, аптечної);

- здійснює контроль за дотриманням суб'єктами господарювання ліцензійних умов провадження господарської діяльності з роздрібної торгівлі лікарськими засобами;

- складає протоколи про адміністративні правопорушення й розглядає справи про адміністративні правопорушення в передбачених законом випадках [10].

Водночас виконувати поставлені завдання Держлікслужба повинна на підставі й у порядку, визначених Законом України «Про основні засади державного нагляду (контролю) у сфері господарської діяльності».

Критерії ризиковості, за якими визначається частота проведення планових перевірок аптек, установлені Постановою Кабінету Міністрів України від 5 червня 2009 року [13]. Позапланові перевірки можуть бути проведені Держлікслужбою на підставі та в порядку, встановлених у ст. 6 Закону України «Про основні засади державного нагляду (контролю) у сфері господарської діяльності» [9].

Ліцензійні умови містять детальні вимоги щодо роздрібної торгівлі лікарськими засобами, зокрема встановлюють вимоги щодо площі аптек й аптечних пунктів, їхнього обладнання, кадрові вимоги до персоналу аптеки. Відповідно до п. п. 156 і 157 Ліцензійних умов роздрібна торгівля лікарськими засобами здійснюється лише через аптеки та їхні структурні підрозділи. Ліцензіат, який провадить господарську діяльність з виробництва (виготовлення) лікарських засобів в умовах аптеки, роздрібної торгівлі лікарськими засобами, забезпечує наявність матеріально-технічної бази, технічних засобів і їхню відповідність вимогам нормативних документів щодо виробництва, зберігання, контролю якості, торгівлі лікарськими засобами [8]. Дотримання вказаних вимог становить предмет державного нагляду у випадку здійснення планової або позапланової перевірки Держлікслужбою.

Підзаконні акти встановлюють перелік вимог, які підлягають перевірці працівниками контролюючого органу під час проведення перевірки. Згідно 3 п. п. 1-4 розділу IV Порядку контролю торгівлі Держлікслужба має право відібрати зразки лікарських засобів для лабораторного дослідження їхньої якості відповідно до затверджених показників. Лабораторне дослідження якості лікарських засобів здійснюється підпорядкованими або уповноваженими лабораторіями на підставі направлень [11]. Окреслене коло проблем свідчить про специфіку предмета державного нагляду у сфері роздрібної торгівлі лікарськими засобами.

Таким чином, є спеціальний порядок державного нагляду у сфері роздрібної торгівлі лікарськими засобами. Специфіка контролю полягає в тому, що зробити висновок про якість лікарського засобу неможливо без проведення лабораторного дослідження.

Порядок і підстави відбору зразків продукції для експертного дослідження встановлені у ст. ст. 12-15 Закону України «Про основні засади державного нагляду (контролю) у сфері господарської діяльності» [9]. Як передбачено у п. 2 Порядку відбору зразків відбір зразків лікарських засобів під час здійснення державного контролю іхньої якості проводиться за рішенням Держлікслужби. Рішення щодо відбору зразків для проведення лабораторного аналізу приймається у таких випадках:

- у разі невідповідності лікарського засобу вимогам специфікації якості за результатами візуального контролю;

- виявлення розбіжностей у супровідних документах до серій лікарських засобів;

- порушення встановлених умов виготовлення лікарського засобу в аптеці за рецептом лікаря, зберігання, транспортування та реалізації 
лікарського засобу, що може негативно вплинути на його якість [12]. Отже, працівники контролюючого органу, здійснюючи перевірку аптеки, повинні виконувати власні повноваження виключно в порядку, встановленому законодавчими і підзаконними актами.

Таким чином, державний нагляд у сфері роздрібної торгівлі лікарськими засобами можна визначити як здійснення спеціально уповноваженим контролюючим органом власних адміністративних повноважень щодо нагляду за дотриманням законодавства, яке встановлює вимоги до якості лікарських засобів, ліцензійні умови роздрібної торгівлі лікарськими засобами та порядок реалізації таких засобів.

Можна визначити особливості державного нагляду у сфері роздрібної торгівлі лікарськими засобами:

1) специфічний предмет такого нагляду: відповідність аптеки ліцензійним умовам щодо роздрібної торгівлі лікарськими засобами та якість лікарського засобу (зокрема, до предмету державного нагляду в цій сфері належить матеріально-технічна база, технічні засоби та ї відповідність вимогам нормативних документів щодо виробництва, зберігання, контролю якості та торгівлі лікарськими засобами);

2) державний нагляд здійснюється спеціальним контролюючим органом, на сьогодні це Державна служба 3 контролю якості лікарських засобів та контролю за наркотиками.

3) спеціальний порядок здійснення наглядових заходів (контроль якості лікарського засобу потребує відбору зразків продукції та проведення лабораторного дослідження);

4) проведення заходу державного нагляду потребує спеціальних знань не тільки у сфері юриспруденції, але й фармації;

5) особлива нормативно-правова база, яка регулює порядок здійснення державного нагляду у сфері роздрібної торгівлі лікарськими засобами, що охоплює не лише законодавчі акти, але й підзаконні акти Кабінету Міністрів
України та Міністерства охорони здоров'я України.

Подальші наукові дослідження проблем державного нагляду у сфері роздрібної торгівлі лікарськими засобами можуть бути пов'язані з дослідженням порядку здійснення окремих контрольно-наглядових заходів Держлікслужбою України.

Статтю присвячено вивченню специціки правового регулювання державного нагляду у сфері роздрібної торгівлі лікарськими засобами. Розкрито сутність державного нагляду та роздрібної торгівлі лікарськими засобами. Акиентовано увагу на особливостях нормативно-правових засад ведення роздрібної торгівлі лікарськими засобами. Окреслено систему нормативно-правових актів, які регулюють порядок здійснення державного нагляду у сфері роздрібної торгівлі лікарськими засобами.

Досліджено повноваження органів державного нагляду щзодо проведення планових $i$ позапланових перевірок аптек. Визначено підстави й порядок проведення таких перевірок. Наведено вимоги ліцуензійних умов, яким повинна відповідати аптека, що здійснюе роздрібну торгівлю лікарськими засобами. Визначено предмет державного нагляду у сфері роздрібної торгівлі лікарськими засобами. Запропоноване власне визначення державного нагляду у сфері роздрібної торгівлі лікарськими засобами. Визначено спещифічні риси здійснення контрольно-наглядових заходів саме у сфері роздрібної торгівлі лікарськими засобами.

Наголошено, що особливостями державного нагляду у сфері роздрібної торгівлі лікарськими засобами e спеиифічний предмет такого нагляду, наявність спеціального органу влади, уповноваженого проводити перевірки дотримання законодавства у цій соері. Встановлено, шо здійснення державного нагляду мож- 
ливе за наявності спеціальних знань не лище у сфері юриспруденції, але й фармації та лабораторного дослідження якості лікарського засобу. Зазначено, шо регулювання здійснення державного нагляду у сфері роздрібної торгівлі лікарськими засобами включае в себе широкий спектр нормативно-правових актів, які містять систему однорідних суспільних відносин, що регулюють фармацевтичну діяльність за допомогою підінститутів обігу лікарських засобів, якими є створення, виробництво, зберігання, транспортування, контроль якості, імпорт, експорт, реалізація та утилізація лікарських засобів.

Ключові слова: державний нагляд, лікарські засоби, роздрібна торгівля, ліцензійні умови, контроль якості.

Khovpun O. Legal regulation of state supervision in the field of retail trade in medicinal products

The article is focused on studying the specifics of legal regulation of state supervision in the field of retail trade in medicinal products. The essence of state supervision and retail trade in medicinal products has been revealed. The author has emphasized on specific features of regulatory principles for retail trade in medicinal products. The system of regulatory acts regulating the procedure of state supervision in the field of retail trade in medicinal products has been outlined.

The powers of state supervisory agencies in regard to conducting scheduled and unscheduled inspections of pharmacies have been studied. The grounds and procedure for conducting such inspections have been determined. The author has provided the requirements of the licensing conditions for a pharmacy that accomplishes retail trade in medicinal products. The subject matter of state supervision in the field of retail trade in medicinal products has been determined. The own definition of the state supervision in the field of retail trade in medicinal products has been offered. The specific features of the implementation of control and supervision measures in the field of retail trade in medicinal products have been defined.

It has been emphasized that the peculiarities of state supervision in the field of retail trade in medicinal products are the specific subject matter of such a supervision, the presence of a special agency authorized to conduct inspections of the compliance with the legislation in this area. It has been established that the implementation of state supervision is possible with the presence of special knowledge not only in the field of jurisprudence, but also in the pharmacy area and laboratory research of medicinal products' quality. It has been noted that the regulation of state supervision in the field of retail trade in medicinal products includes a wide range of regulations that contain the system of homogeneous social relations regulating pharmaceutical activities through sub-institutions of the circulation of medicinal products, which are the creation, production, storage, transportation, control over the quality, import, export, sale and disposal of medicinal products.

Key words: state supervision, medicinal products, retail trade, License conditions, control over the quality.

\section{Література}

1. Синицький П.В. Форми контрольно-наглядової діяльності Державної служби охорони при МВС України. Підприємництво, господарство $i$ право. 2009 (163). № 7. C. 15-18.

2. Правдюк А.Л. Удосконалення правового статусу органів, які здійснюють митний та прикордонний ветеринарний контроль та нагляд за станом сільськогосподарських тварин. Проблеми правознавства та правоохоронної діяльності : збірник наукових працьь. 2008. № 2. С. 74-84.

3. Теремецький B.I. Податкові правовідносини в Україні : монографія. Харків : Диса плюс. 2012. 648 с.

4. Соловйов О.С. Організація діяльності аптек. Актуальні питання фармацевтич- 


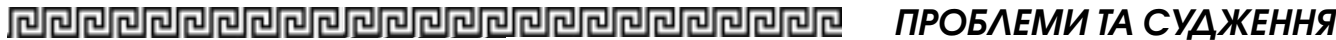

ної і медичної науки і практики. 2019. Т. 12. № 2 (30). C. 215-221.

5. Кущ Л. І. Виробнищтво лікарських засобів та торгівля ними як види господарської діяльності. Правничий часопис Донеиького університету. 2004. № 1 (11). С. 29-34.

6. Васильев С. В. Нормативно-правове регулювання роздрібної торгівлі лікарськими засобами. Підприємництво, господарство і право. 2018. № 1. С. 41-44.

7. Про лікарські засоби : Закон України від 4 квітня 1996 р. № 123/96-ВР. Відомості Верховної Ради України. 1996. № $22 . \mathrm{Cm} .86$

8. Про затвердження Лічензійних умов провадження господарської діяльності з виробниитва лікарських засобів, оптової та роздрібної торгівлі лікарськими засобами, імпорту лікарських засобів (крім активних фармацевтичних інгредієнтів) : Постанова Кабінету Міністрів України від 30 листопада 2016 р. № 929. Офініüний вісник України. 2016. № 99. Ст. 3217.

9. Про основні засади державного нагляду (контролю) у сфері господарської діяльності : Закон України від 5 квітня 2007 р. № 877-V. Відомості Верховної Ради України. 2007. № 29. Ст. 389.

10. Про затвердження Положення про Державну службу України з лікарських засобів та контролю за наркотиками:
Постанова Кабінету Міністрів України від 12 серпня 2015 р. № 647. Офіиійний вісник України. 2015. № 72. Сm. 2354.

11. Про затвердження Порядку контролю якості лікарських засобів під час оптової та роздрібної торгівлі : Наказ Міністерства охорони здоров'я України від 29 вересня 2014 р. № 677. Офіиійний вісник України. 2014. № 98. Ст. 2857.

12. Про затвердження Порядку відбору зразків лікарських засобів для лабораторного аналізу під час здійснення державного контролю якості таких засобів : Постанова Кабінету Міністрів України від 3 лютого 2010 p. № 260. Офіційний вісник України. 2010. № 17. Ст. 786.

13. Про затвердження Критеріїв, за якими оцінюеться ступінь ризику від провадження господарської діяльності у сфері виробниитва лікарських засобів, оптової $i$ роздрібної торгівлі лікарськими засобами, імпорту лікарських засобів (крім активних фармацевтичних інгредієнтів) та у сфері контролю якості лікарських засобів i визначається періодичність здійснення планових заходів державного нагляду (контролю) Державною службою лікарських засобів та контролю за наркотиками : Постанова Кабінету Міністрів України від 5 червня 2009 р. № 465. Офіційний вісник України. 2019. № 48. Ст. 1640. 